\title{
Crafted by Many Hands: Re-Reading Bronislava Nijinska's Early Memoirs
}

LYNN GARAFOLA

In 1981 Bronislava Nijinska's Early Memoirs, the last autobiography by a major figure in Diaghilev's Ballets Russes, was published to near universal acclaim. However, as the choreographer's notes, drafts, and early autobiographical manuscripts make clear, Early Memoirs is a composite work, crafted by multiple hands and harbouring within itself alternative and even contradictory readings of the dominant story. In a field that privileges firstperson testimony, the composite nature of most dance autobiographies is highly problematic, at once undermining their narrative authority and forcing recognition of what might be called their multivocality. Early Memoirs, like other volumes of dance autobiography, belongs both to Nijinska and to her interpreters, even if their interests do not always coincide.

In February 1982, in a review of Bronislava Nijinska's Early Memoirs ${ }^{1}$ published in The Dancing Times, I wrote:

With the publication of... Early Memoirs, the last and finest of the Diaghilev-era memoirs has been written. As a narrative of pre-War Russian ballet, both within the Tsarist Empire and abroad, and the saga of a choreographer's personal and artistic journey, it is unsurpassed in the wealth of its detail, the honesty of its revelations, and its vindication, with the passion Nijinska demonstrated throughout her life, of the choreographic genius of Vaslav Nijinsky. ${ }^{2}$

Although I continue to find Early Memoirs a compelling 'read', today my admiration is tempered by the knowledge that the volume did not spring solely from the memory of its author. Rather, it has become clear that like so many dance autobiographies, Early Memoirs is a composite work, crafted by multiple hands, augmented, reordered, rearranged, and put into English by editorial midwives whose concerns do not always dovetail with the author's. In content, style, and voice, Early Memoirs differs significantly from what Nijinska actually wrote and the story she wanted to tell. Where Early Memoirs is a

Dance Research 29.1 (2011): 1-18

Edinburgh University Press

DOI: $10.3366 /$ drs.2011.0002

(C) Society for Dance Research

www.eupjournals.com/drs 
ballet story peopled with the Maryinsky and Ballets Russes stars who figured so prominently in biographies and memoirs published and reprinted in the $1970 \mathrm{~s},{ }^{3}$ the manuscript on which it is based, 'My Brother Vaslav Nijinsky, ${ }^{4}$ is the intimate story of a family and its bonds, a creative twinship that ended in a Vienna sanatorium, and an artist's subjectivity expressed through the written word.

Although Nijinska published little in her lifetime, she wrote continuously. 'I remember you asked me if I used to write before, and I answered "a little", she told the critic André Schaikévitch in 1971. 'In fact, I always wrote, just for myself..., starting at a very young age. ${ }^{{ }^{5}}$ The Bronislava Nijinska Collection, now housed in the Music Division of the Library of Congress, runs to hundreds of boxes. There are the diaries and journals that she began to write during her years in Kiev, when she created her first experimental dances; multiple versions of her treatise 'Movement and the School of Movement', and an even earlier treatise, 'The School and Theater of Movement', drafted in 1918 at the very moment of her artistic transformation in the wake of the Revolution. ${ }^{6}$ There are detailed notebooks about individual ballets, including those choreographed for her short-lived companies, drafts of her extensive correspondence, and a number of autobiographical manuscripts. Although she read several languages and had lived outside Russia since 1921, she wrote only in Russian - the language of her inner life.

Thanks to the opening of the Nijinska Collection, it is possible for the first time to trace the gestation and evolution of Early Memoirs. In the 1960s Nijinska began to work seriously on a volume of reminiscence. In an interview with The Guardian in 1964, when she was in London staging Les Biches for the Royal Ballet, she told the critic James Kennedy that her main concern

is that she should at last produce her book, long prepared and often corrected, about her brother, not about his life but about his art. Much... has been written about him and written badly because it was done by people who did not really understand his technique, his art, his genius. ${ }^{7}$

The manuscript, which was titled 'My Brother Vaslav Nijinsky' (although Nijinska's daughter and literary executor, Irina Nijinska, referred to it in conversation as 'My Brother Vatza') ${ }^{8}$ went through numerous transformations. Chapters were written and rewritten, copied and corrected, sometimes on separate sheets, more often in notebooks from the many countries where she lived and worked. By 1970 the manuscript was complete, save for the last few pages; it had been edited by Anatole Daroff, an émigré writer and journalist, ${ }^{9}$ and turned over to Natalie Wollard, who seems to have been a family friend, to translate. ${ }^{10}$ By now, Nijinska was anxious to end her decades of literary silence. In 1968 she sent three chapters, including the one on Diaghilev, to Professor George Ivásk, who taught in the Germanic and Slavic Department at Vanderbilt University, to consider for publication in the literary-artistic journal Mosty (Bridges), to which Daroff, as well as Nijinska's California friend, the composer Vernon Duke, were regular contributors. (Duke published verse and the occasional essay on 


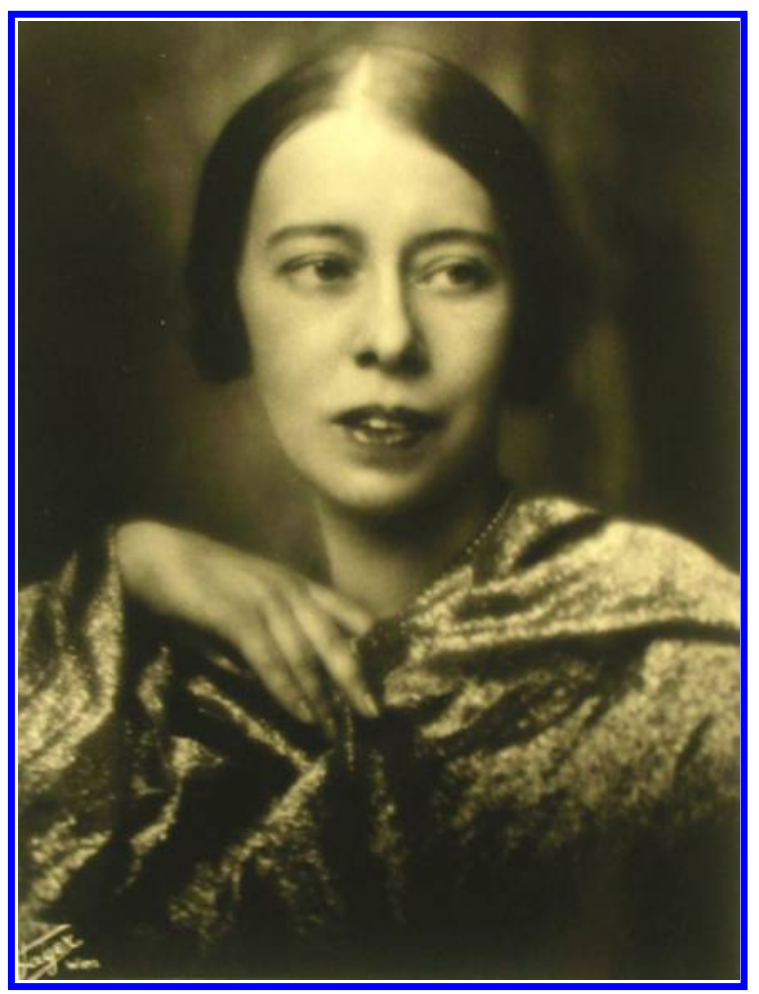

Fig. 1. Bronislava Nijinska, Vienna, 1930. Photo by Fayer. Bronislava Nijinska Collection, Library of Congress.

music under his birth name, Vladimir Dukelsky.) ${ }^{11}$ Ivásk loved the chapter on Diaghilev. 'I never saw him, but now I see him: you bring him to life. ${ }^{12}$ However, nothing came of this venture, and Mosty itself went out of existence in $1970 .{ }^{13}$

By 1971, Nijinska had grown increasingly concerned about the slow pace of translation. Wollard had been at work for a year and had thus far translated only a third of the manuscript's 450 pages. ${ }^{14}$ Wollard's mother had been ill, and Wollard herself seems to have been extremely busy. But the project was slowed, too, by Nijinska's own busy schedule, which took her away from California for weeks at a time, and by her limited English. She relied on her daughter, Irina, to read over Wollard's translation and then retranslate it back into Russian so that Nijinska could judge the accuracy of Wollard's work. Through this onerous process, Nijinska discovered inaccuracies that originated not in the translation but in Daroff's editing, which Nijinska, because she was often away, hadn't bothered to check. Meanwhile, with 1972, the centenary of Diaghilev's birth, rapidly approaching, she had received several offers to publish her book. She had been asked to submit the manuscript 'as is', being assured there was no problem finding a good, experienced translator. However, Nijinska rejected the offers, preferring to keep the manuscript close at hand, where she could not only supervise its progress but also prevent it from falling into the wrong hands. 
Assuring publishers that she had a good translator already, she reiterated in her letters to Wollard that she should show neither the Russian original nor the English translation to anybody. Two books about Nijinsky were coming out in the Soviet Union, another in London, and she was being constantly asked for information about her brother's family and childhood..$^{15}$ In addition, there was Maurice Béjart's Nijinsky: Clown of God. The ballet, which premiered in Brussels in 1971, outraged her (although she had never seen it), probably because it dealt openly with the dancer's sexual relationship with Diaghilev. Never had the publication of her book seemed more timely. ${ }^{16}$

In the surviving drafts of her letters to Daroff and Wollard, Nijinska often alludes to the need to find an agent. Her sister-in-law Romola recommends one, but Nijinska rejects him, because he is handling not only all of Romola's books but also a film about Nijinsky. ${ }^{17}$ However, as it turns out, Nijinska was in touch with a New York literary agent named Bertha Klausner. 'Our mutual friend Vernon Duke telephoned last night to tell me that you had completed your manuscript,' she wrote to Nijinska in June 1968. 'I don't know whether you will remember that I had contact with you more than ten years ago and hoped then that we might be able to get together on your personal story. ${ }^{18}$ Nijinska responded some months later, stating that she was anxious 'to see my book published as soon as possible' and looked forward to working with Klausner. ${ }^{19}$ In less than two weeks, Klausner responded:

I am delighted to hear from you and to know that you will be sending me your manuscript in the early future.

I understand from Vernon Duke that he thinks that our mutual friend Anatole Daroff would make a good translator for your book.

The documentary record ends here.

After Nijinska's death in February 1972, the project stalled. In 1974, Jean Rawlinson, an aspiring novelist and friend of Irina, contacted Paul McClusky of Harcourt Brace Jovanovich about publishing projects based on materials from Nijinska's library, such as the 1847 Natural History of the Ballet-Girl illustrated with prints from her collection. Rawlinson casually mentions that Nijinska's 'first book of memoirs is in the hands of the Don Shepherd Agency, Reseda, California, until March $1974{ }^{2} .^{20}$ Neither the publisher nor the literary agent seems to have accomplished anything, and at some point Rawlinson contacted Klausner about the 'old book' as well as a proposal for a biography of Bronislava Nijinska with the title 'La Nijinska-Reminiscences of a Choreographer' that would capitalise on the skyrocketing interest in women artists that accompanied second-wave feminism. Rawlinson explained what she and Irina had in mind:

We are hoping to produce a book that will not only be a readable book concerning the life of an artist who worked with and influenced many of the great artists, whether in painting, dance, theater, music, films during the first three-quarters of the $20^{\text {th }}$ century, but also one which will fill a gap in the history of the Dance as it will be concerned with the work and philosophy of a great woman choreographer. ${ }^{21}$ 
Klausner was unimpressed by the new proposal. 'What has happened to the autobiography?' she asked.

I was under the impression that I would receive Bronislawa's [sic] autobiography. She wrote me a number of times that she was writing it, and writing it in Russian. Vernon Duke told her that we could have it translated in New York.

Presciently, she added: 'If Irina wishes, she may be able to write a book about her mother and use the material for the book. It will be better that way, as Irina can go on the talk shows. ${ }^{22}$

Later that year Irina and Rawlinson produced their first publication together. Entitled 'Creation of 'Les Noces": Bronislava Nijinska,' this was a reminiscence by Bronislava of her Diaghilev-era masterpiece commissioned but never published for the 1966 Royal Ballet revival of Les Noces. (Once rehearsals began, the editor/translators explained, 'it was not possible, in that short time, to work out an adequate translation and so she withheld her permission for publication'.) ${ }^{23}$ Now the memoir appeared in Dance Magazine with a brief introduction by the editorial midwives and illustrations from Nijinska's collection. Presumably, the success of the article and of the collaborators' working method led them to return to Nijinska's book manuscript. Doubtless, too, they had come to realise how daunting an undertaking a full biography would be, given the complexity of Nijinska's life and work, the fact that virtually all the primary material was in Russian (which Rawlinson did not read), and that Nijinska's later autobiographical writings, when they existed, were extremely fragmentary. The Wollard translation was totally abandoned, although it may have served as the skeleton, albeit uncredited, of the first several chapters of Early Memoirs.

The book's lengthy gestation very significantly transformed the volume that Nijinska had both written and done everything in her power to control in terms of editing, translation, and publication. She trusted nobody but her family - her husband, Nicholas Singaevsky, until his death in 1968, her daughter, Irina, subsequently - and a small émigré circle of friends. Irina's friendship with Jean Rawlinson, described in Early Memoirs as 'a writer then engaged in research for a historical novel set in Tsarist and Revolutionary Russia' (xxii), took her outside that circle. Rawlinson brought a fictional impetus to the project, a drive to set Nijinska's story within the rich panorama of Russian history, the world of glamorous ballerinas like Anna Pavlova and Mathilde Kschessinska, Robert Massie's Nicholas and Alexandra, and Boris Pasternak's Doctor Zhivago. Irina had praised Wollard's translation as a 'literal' one, meaning that it was extremely accurate, even though Wollard herself had called it a draft (meaning that it needed polishing). ${ }^{24}$ Now Irina embarked on a project to remake the memoir of her mother's life as a romance of late Imperial Russia.

In stitching together the manuscript for Early Memoirs, Irina and Rawlinson made numerous changes, which they explain somewhat disingenuously in the Editors' Foreword as a process of fact checking and enhancing the narrative flow (xxiii). To be sure, some of these changes reflect the customary norms of 
'silent' editing. Everyone acquired a full name along with a brief biography; dates and titles were corrected, obviously misplaced material was shifted. At the same time an expansionary trend was at work. Early Memoirs is a much bigger and longer book than 'My Brother Vaslav Nijinsky', thanks to the addition of a thick layer of descriptive-explanatory fact that 'fleshes out' Nijinska's unadorned account of events, as if to give it greater historical weight. This spareness is still evident in 'The Dancing Family of Nijinsky's - 1854-1914', a very early draft of what became Early Memoirs. ${ }^{25}$ But the longer the translator/editors laboured over their task, the more they apparently felt compelled to elaborate. Where typically Nijinska begins her chapters with a simple declarative statement, her editors append at least one or two paragraphs (and often more) of explanation. Thus, the chapter on Nizhni-Novgorod opens with a vivid, but interpolated, description of its 'Great Annual Fair', with 'traders from all over Russia and... many parts of Asia' selling carpets, furs, precious stones, porcelains, silks, and silver (30). The influential St. Petersburg teacher Enrico Cecchetti barely appears in the original account of Nijinsky's audition for the Imperial Theatrical School, but the colorful Italian is very much present in Early Memoirs, where we learn not only that Eleanora Nijinsky pleaded with him to intervene on her son's behalf, but also that in 1887 she and her husband, Thomas Nijinsky had danced in two of the Maestro's ballets (74). By contrast, in 'My Brother Vaslav Nijinsky', Nijinska tells us that Eleanora pinned her hopes on Stanislav Gillert, a Polish dancer who taught in the Girls Division of the School. He 'actively interceded for Vaslav', wrote Nijinska, helping her mother submit the application, and then 'endeavor[ing] to tell many members of the commission that Vaslav was a very talented child and [the] son of a well-known dancer and ballet-master of Russian private theatres'. ${ }^{26}$ Although Gillert's assistance is acknowledged in Early Memoirs (75-6), Eleanora now 'depended very much' on the actress Cleopata Karatyguina and the Maryinsky singer Joachim Tartakov (49), both mentioned in the earlier manuscript only in passing. ${ }^{27}$

Something is certainly gained by these interpolations. In the chapter on Novaya Derevnia ('The New Village'), a summer resort on the outskirts of St. Petersburg, and in many of the book's early chapters, we end up learning a great deal about the little known performance world outside the Imperial Theatres in which Nijinska's parents, Thomas Nijinsky and Eleanora Breda, spent their lives as itinerant Polish dancers. Nijinska herself, in 'My Brother Vaslav Nijinsky', amplifies her memories of the resort's summer theaters, paraphrasing, for instance, the critic Konstantin Skalkovsky's admiration of its well-equipped stages and noting the many celebrated Italian ballerinas who danced there. Yet she ends the paragraph about them very simply: 'Our parents took part with these ballerinas in many... productions by Setov and Lentovsky. ${ }^{23}$ No mention here-as in Early Memoirs-that 'Mother and Father had previously worked in all three of the Novaya Derenvia theatres', or that in 1885 'they had appeared in Lentovsky's fantastic spectacular, Trip to the Moon,... when Virginia Zucchi and Maria Giuri had danced for the first time in Russia'; no footnote about the 


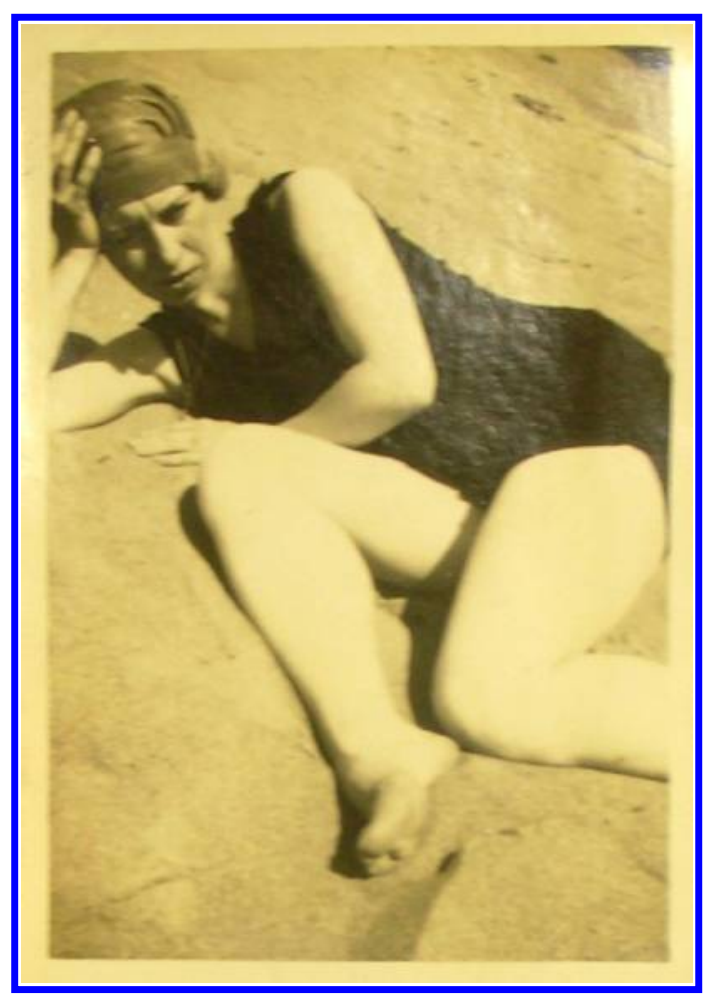

Fig. 2. Bronislava Nijinska on the beach, 1920s. Bronislava Nijinska Collection, Library of Congress.

ballerinas' relative artistic merits; no direct quotation from Skalkovsky's book In the Theatrical World (48).

Material was not only added to Early Memoirs but also excised from it. The following manuscript passage, for instance, which describes the six-yearold Bronia's emerging subjectivity, the unravelling of her parents' marriage, and the sadness that seems to haunt so many of her writings, disappeared from the published volume:

It seems to me that this summer my carefree childhood ended forever. That time was too sorrowful for the soul of a six-year old girl. I began very early to understand many painful events in the life of grown-ups and felt them very painfully. Even my father began to notice my too great 'comprehension'....

'Bronia is an incredibly developed child,' he said once in [a] whisper to a friend... This sentence remained in my memory because for a long time I could not understand what this word 'developed' could mean, and decided, that probably it was some evil vice in me, if father was talking about it in a whisper...

Our parents never talked in the presence of children about their personal relationship, but by many signs, imprudently said sentences, and above all by my feeling, I knew that some important sorrowful changes were happening my our family.

I never saw my mother crying but I felt that she was suffering. .. and tried with all her strength to conceal her emotions from us.... I loved my mother very much, 
I admired her and told her constantly: 'Mama, you are so beautiful, more beautiful than ever,' but Mama only smiled sadly. ${ }^{29}$

Some of this language reappears in Early Memoirs toward the end of the Novaya Derevnia chapter (56-7). But the passage has been broken up. Each sentence, now, seems wrapped in a layer of interpolated detail - the name of Thomas Nijinsky's lover, an explanation of how they met, his arguments with Eleanora when they returned from the theatre at night, the reaction of the brothers, Vaslav and Stassik, to the impending break - muffling Nijinska's singular voice and the child Bronia's pain.

In some cases, the editors' interpolations appear to stem from a desire to make Nijinska's personal story conform to a familiar, documented history. Her account of the first time she saw Isadora Duncan dance (in November 1908) is more than twice as long in Early Memoirs than in the Russian drafts on which it is based. The Russian text is quite straightforward:

When Duncan performed at the Suvorin Theater, Pavel Dmitrievich [Lvov] took a box so that I wouldn't feel shy sitting in public as in the parterre. About Duncan I had already heard a lot for a long time, but I had still not seen her dance. She was appearing in Petersburg for the second time, and everyone already knew her well as an artist and awaited her....I don't remember whom Vaslav invited to the box-whether M [ichel]. Fokine and Vera Fokina or T[amara]. Karsavina and her husband or anyone else-I remember only that during the intermission after the first part of the performance many people collected around Vaslav in the box; all were clamoring but Vaslav most of all.

That evening I saw not only Duncan, who had such a big influence on the innovative passions of Fokine, but I also heard many outspoken artists and critics and discussions for and against reform in ballet along Duncan's 'lines'.... I remember that Vaslav... protested and spoke hotly and passionately against the Duncan enthusiasm and insisted that progress in ballet could [take place] only through the steps of the classical ballet school and not by [embracing] Duncanism; he only sees in Duncan progress in the artistic-creative side of ballet.

The next morning... the Inspectr[ess] and the 'class lady' [governess] asked me to demonstrate how Duncan danced. In the hall... I tossed off my shoes, and in only my stockings I began to imitate Duncan dances. I ran, skipped, waved my hands, knelt, and stood in other poses. I had to say that I liked Duncan very much and that she had left a big impression on me. All the girls laughed a lot. ${ }^{30}$

The account in Early Memoirs is very different. The introduction situates the performance with great specificity: we learn the date of Duncan's first Gala Benefit Performance at the Maryinsky (8 February), and that she danced at the Suvorin Theatre for the next two weeks (223). The section ends with a long interpolated passage about the dozen or so pupils who appeared with Duncan: they came from her school in Berlin, wore white tunics and flowers in their hair, and 'weaved in and out in endlesss rounds until Duncan herself came on and danced with them' (225). Most surprising, however, is the description of the 'memorable evening' itself:

I saw for myself the dancing of Isadora Duncan, which I knew was admired by Kschessinska and Pavlova and had also influenced Fokine in his new choreography. I also 
heard many opinions on the future of ballet voiced by dance critics and artists who came to our box during the intermission.

Prince Lvov had invited Tamara Karsavina and her husband, Vasily Moukhin, to share our box. Karsavina had just been promoted to the rank of première danseuse and was popular with the balletomanes, who admired the fact that in Swan Lake just a month before in January, she had dared to be different by dancing not the usual, expected, thirty-two fouettés in Act III but a brilliant variation of her own. (224)

Colourful, anecdotal, and irrelevant 'filler'-included, I suspect, to enliven Nijinska's narrative and 'humanise' it. But the passage also has the unintended consequence of undermining the very impact of Duncan's work, its appeal for the wide-eyed ballet student, whose later experimental choreography all but abandoned the aesthetics of the late Imperial stage. (Indeed, in her sprawling 1918 treatise, 'The School and Theatre of Movement', Nijinska claimed that she left the Imperial stage after three years 'not having seen any genuine art there'. $)^{31}$ A few paragraphs on, another effort is made to neutralise Nijinska's artistic openmindedness, this time by identifying her point of view with a bona fide member of the ballet establishment:

Although I remained silent, I agreed with Vaslav when he said he felt that progress should be achieved not by discarding the classical ballet school in favor of Duncanism but rather by seeking new ideas in the presentation of ballet. But then I also agreed with Karsavina who felt there was room for both forms of dancing - the art of Duncan and the art of classical ballet. Each could only gain and be enriched by observing the other. (224)

This apparent desire on the part of the editors to 'fit' Nijinska's story to the standard ballet narrative of the 1960s and 1970s is evident as well in the numerous references to Anna Pavlova. For Nijinska, the ballerina was her brother's ideal partner, although they seldom danced together, an embodiment of the 'movement' that Nijinska tries so hard to define in her treatise 'On Movement and the School of Movement'. ${ }^{32}$ In 'My Brother Vaslav Nijinsky', she includes a chapter on the two of them dancing together, and in an even earlier autobiographical work, she devotes a chapter to their rehearsals for Giselle. ${ }^{33}$ However, the references to Mathilde Kschessinska in Early Memoirs are equally numerous, and this is inexplicable except for the fact that she was a ballet legend, only dying in 1971 in Paris at the age of ninety-nine. Although the prima ballerina assoluta certainly took an interest in Nijinsky, inviting him to partner her, she exemplified pretty much everything that Nijinska abhorred about the Imperial stage - the corruption, stagnation, bureaucracy, to say nothing of the cult of the ballerina and the worship of virtuosity, which Nijinska parodied in her variation for the Street Dancer in Petrouchka and spent pages denouncing in her 1918 treatise.

'My Brother Vaslav Nijinsky' was written over a long period of time. Because Nijinska seldom dated any of her drafts, it is unclear when she started working on it and how the manuscript evolved. There is evidence, however, that she added to the basic text from time to time. Thus, in the late 1960s, when she was in correspondence with the Soviet dance historian Vera Kraskovskaia and 


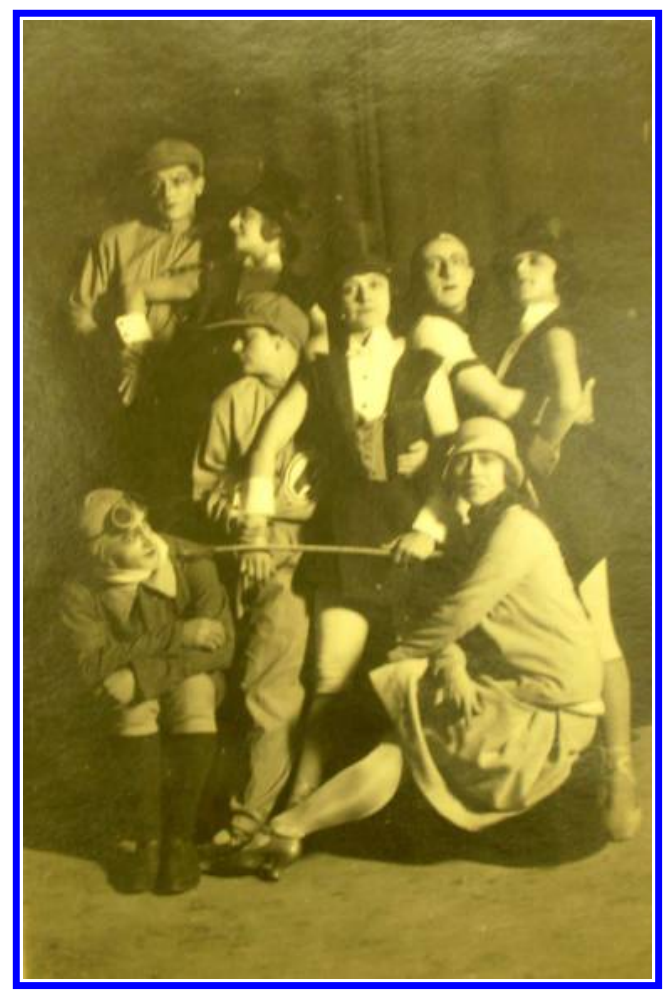

Fig. 3. Bronislava Nijinska (lower right), with dancers from her Theatre Choréographique in the ballet Touring, 1925. They are wearing costumes designed by Alexandra Exter. Bronislava Nijinska Collection, Library of Congress.

at her request reviewed the section on Nijinsky in her history of early twentiethcentury Russian ballet, Nijinska almost certainly incorporated material about her brother's early career that she herself did not personally witness or that she lacked documentation for. This includes her brother's first performance of the Bluebird pas de deux from The Sleeping Beauty, attributed in Nijinska's Russian typescript as coming from Krasovskaia's book. ${ }^{34}$

Irina, too, did her research. She seems to have looked long and hard at Richard Buckle's biography of Nijinsky, published the year before Nijinska's death. In Early Memoirs, she and Rawlinson go to great lengths to correct a Debussy letter misquoted in Buckle, asserting, however, that it was Debussy's biographer, Edward Lockspeiser, who has misquoted it. ${ }^{35}$ And they added several pages (152-4) about the events of 1905, which Buckle discusses but are entirely absent from Nijinska's Russian manuscripts. Buckle did not read Russian, nor does he appear to have worked with a Russian-speaking research assistant. His source in this instance is Tamara Karsavina's classic memoir, Theatre Street. ${ }^{36}$ Karsavina had been among the 'ringleaders' of the 1905 strike, as were Pavlova and Fokine (along with a number of lesser lights). Karsavina was already a professional dancer; Nijinsky, however, was still a student. So Irina turned to 
Russian sources to reconstruct the events that shook the Imperial Theatrical School in the autumn of 1905, even though there was no hard evidence that Nijinsky had participated in them. Her first major source was a slim volume published in Soviet Russia in 1926 entitled The Imperial Theaters and 1905. ${ }^{37}$ The author was Vladimir Telyakovsky, the Director of the Imperial Theatres from 1902 until 1917, when the theatres were nationalised by the new Soviet government. Telyakovsky kept voluminous diaries, in which he recorded in detail and on an almost daily basis everything of interest that went on at the Petersburg theatres. Irina loosely translated long passages from Telyakovsky's book, creating a rough chronology of events, writing 'BN' in the margin when Telyakovsky mentions a ballet (like Coppélia) in which Nijinska danced. ${ }^{38}$

Irina's second major source was a treasure-trove. In 1938-9, the Kirov Ballet celebrated its $200^{\text {th }}$ anniversary with the publication of two thick volumes compiled by Mikhail Borisoglebsky. ${ }^{39}$ There was something quixotic about a publication commemorating a Tsarist institution appearing at the height of the purges, given that Stalin's terror was intended, in part, to eliminate surviving vestiges of pre-Revolutionary culture. In any event, Irina combed the second volume, which covered the years 1888-1918, translating page after page of School rules and regulations - the grading system, academic schedule, scholarships, what students were expected to learn in subjects like history, Russian, science, and embroidery, and what they studied from year to year in their 'special', that is, dance-subjects. Borisoglebsky included biographies of significant figures, libretti, programs, reviews, excerpts from unpublished memoirs (such as Maria Gorshkova's), and long passages from Telyakovsky's 1905 diaries. Irina made rough translations of material that interested her, and since, like her mother, she saved everything, her notes allow one to glimpse not only the process of her research but also something of the intent behind it. ${ }^{40} \mathrm{Just}$ as Buckle's biography was anchored in a documentary history that had grown up in the West in the decades following the collapse of the Ballets Russes, Nijinska's story rested on Soviet sources and a historiography largely ignored by Western dance writers - a reminder of the long shadow cast by the Cold War on dance scholarship.

Nijinska organised her memoir both chronologically and thematically. In revising the manuscript, the editors did away with most of the thematic chapters, absorbing them into a strict chronological narrative. In her drafts of 'My Brother Vaslav Nijinsky', Nijinska devoted an entire chapter, 'Prince Lvov: Friend of Our Family', ${ }^{41}$ to her brother's first 'protector', but in Early Memoirs the chapter title is dropped and the information scattered over several chapters, as if respecting the integrity of Nijinska's vision were less important than minimising the family's willingness to accept Lvov's relationship with Nijinsky and his financial help. Her chapter on 'Sergei Pavlovich Diaghilev' was all but dismembered. The songbird anecdote remains (Eleanora had invited Diaghilev for tea, and the uncaged pet 'opened [its] beak and jumped wickedly' on the impresario's chest!), but the most significant parts, both of which recount events from the 1920 s, were cut - presumably held back for a 'second volume' that never, in fact, materialised. 


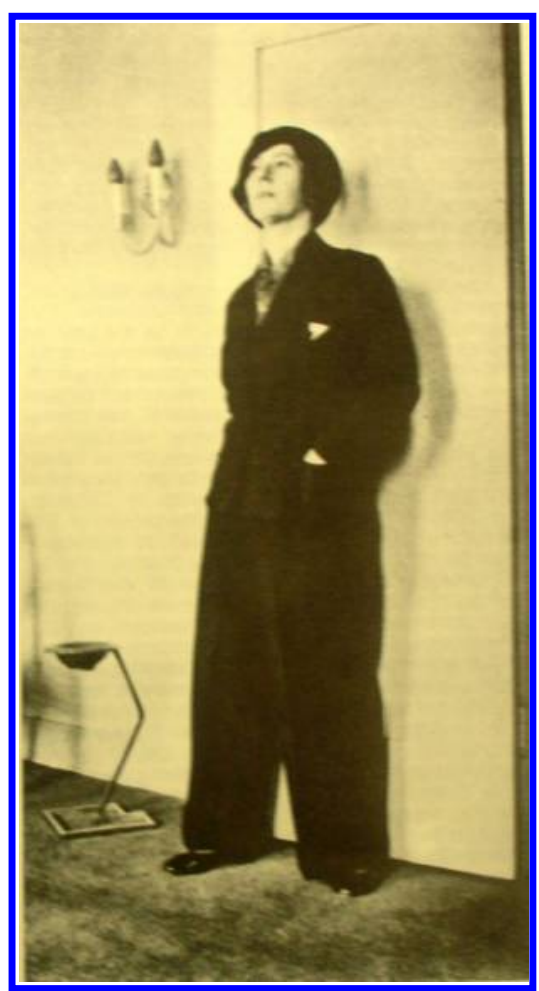

Fig. 4. Bronislava Nijinska, possibly taken in Vienna in 1930, when she briefly worked at the Wiener Staatsoper. Reproduced from the Wiener Staatsoper brochure Les Noces, published in conjunction with the revival of the ballet during the 1987-8 season. Bronislava Nijinska Collection, Library of Congress.

The excised material included Diaghilev's response to the 1922 Paris season of Alexander Tairov's Kamerny Theater, his first glimpse of Soviet experimental stagecraft; his 'malicious' criticism of Nijinska's work outside the Ballets Russes; and his heart-to-heart talk with her late one night in Monte Carlo strolling on the terrace of the Casino. There is also the priceless response of her four-yearold son, Léon, to Diaghilev's question: 'Levoushka, do you know who I am?' 'Of course I know: you are the big, fat Diaghilev.' At which Diaghilev turned to Nijinska, not to reprimand her but to ask, 'Bronia, do I look fat?'+2 One can only rue the editorial decision to drop this.

As noted earlier, Nijinska wrote continuously. She used writing to access her subjectivity, to speak of the pain, depression, and unhappiness that she hid from the world at large. As she told André Schaikévitch, she wrote 'to ease my soul'. ${ }^{43}$ Hence, the reason that she published so little in the 1920s and early 1930s and gave so few interviews. ${ }^{44}$ Indeed, what seems to have galvanised her to action was the publication of Romola Nijinsky's biography of her husband in $1933 .{ }^{45}$ The following year, on her way to Hollywood to film Max Reinhardt's A Midsummer Night's Dream, Nijinska told a journalist that she 'did not esteem highly' Romola's 
biography, which was 'full of inaccuracies' ${ }^{46}$ When she returned to New York in 1936 to stage Les Noces, Irina remembers her mother telling a reporter that Anatole Bourman's book, The Tragedy of Nijinsky, which had just been published, ${ }^{47}$ was 'a novel-a fairy tale', and that 'she was presently working on her own memoirs about her brother Vaslav, his life and creativity, as his sister' ${ }^{48}$ This dovetails with the earliest outline for an autobiographical manuscript that I have found, which seems to date from 1935, as it mentions 'Hollywood', but not her revival of Les Noces or her involvement with either the Polish Ballet or the Markova-Dolin Ballet, both of which absorbed much of Nijinska's energy in the late 1930s. ${ }^{49}$ By 1942, she had produced a slim volume with the title 'From the Diary of a Young Dancer, 1910-1912'. ${ }^{50}$ This was a series of short impressionistic chapters, written in the voice of the young Nijinska, about the early years of the Ballets Russes. She touches on her own creative breakthroughs, her fatal encounter with Chaliapin, Nijinsky's ineffable dancing with Pavlova, and the forging of a new dance language in L'Après-midi d'un faune. By 1942 the volume was translated, but for some reason it was never published, even in serial form. However, cut and pasted, it provided the foundation of the autobiographical manuscripts that followed.

For the most part Nijinska did not identify this material as coming from the 1942 unpublished volume. She merely absorbed it into the manuscript that took shape in the 1960s. The editors did not delete this earlier material from Early Memoirs, but set it off, printing it in a different font size and alternately describing it as 'my notes from those days' (315), 'my diary' (327), or 'Pages from the Diary of a Young Dancer' (332). An editors' note explains:

When Bronislava Nijinska composed her continuous narrative of her early memoirs she retained these pages in their original spontaneous note form.... In discussing the format of her memoirs she resisted any suggestion that these pages be transposed into a continuous form or that the more personal writings be eliminated, declaring, 'The diaries are the soul of my book... as my love for Chaliapin has been the inspiration for my work for the rest of my life.' (332)

Although the 'diary' passages do not appear to rest on actual diary entries from the 1910s, they introduce a younger, more intimate voice into the narrative. This younger Bronia is the sole witness to events experienced by herself and Vaslav; she not only refutes Romola Nijinsky's version of events, but also privileges the creative experiences that Nijinska deems vital to their being as artists. The 'Diary' voice speaks without irony or hindsight; it is fragmented and almost painfully subjective, unlike the book's 'through' voice, which is both 'adult' and authoritative. The presence of these two voices in Early Memoirs suggests one aspect of what I consider its multivocality. By this I mean that the very process of the book's creation is absorbed into the final product.

If Early Memoirs recovers the lost autobiographical voice of Nijinska's 1942 'Diary', it also embodies the vision and working method of its twin editors, Irina Nijinska and Jean Rawlinson. Although they worked as a team, they brought different strengths to the project. As a Russian speaker and as her 
mother's heir, Irina waded through stacks of handwritten notes and drafts, tapping her own memories and ploughing through ballet literature in multiple languages. Both her scrupulousness and persistence compel admiration, as does her willingness to transform the Russian she had spoken since birth into an active language of research. Rawlinson, for her part, was the wordsmith, who created the book's larger narrative frame. The Nijinska we hear is the voice crafted by Rawlinson - naive, feminine, truth-bearing, almost Tolstoyan in its Russianness and embrace of what Nijinska called her country's 'vast spaces'. ${ }^{51}$ Just as important, Rawlinson's questions drove the narrative forward. In 1992 I had lunch with her and a literary agent in Pacific Palisades to discuss the possibility of editing a second volume..$^{52}$ In answer to my question about her working method, she said that Irina would bring her a rough translation, which she would edit. Often, she had questions, which Irina would answer, consulting sources in her mother's library; then Jean would work the new material into the text. So Jean, by her questions, and Irina, by her answers, added their voices to Nijinska's in the manuscript. The volume as published reflects the judgments, preoccupations, and artistic values of all three women.

Although interest in dance autobiography has grown in recent years, the crafting of the written memoir-its sources, the process of its composition, and the multiple forms of authorship embedded in its text-remains little analysed. In a field that privileges first-person testimony, the composite nature of most dance autobiographies - including 'classics' of the field such as Isadora Duncan's My Life, Michel Fokine's Memoirs of a Ballet Master, and Martha Graham's Blood $M_{e m o r y}{ }^{53}$-is highly problematic, at once undermining their narrative authority and forcing recognition of their multivocality. Viewed in this light, a text like Early Memoirs harbours within itself multiple narratives, including alternative and even contradictory readings of the dominant story. Like an old ballet that has absorbed the contributions of multiple generations of dancers, Early Memoirs belongs both to Nijinska and to her editors, even if their interests do not always or necessarily coincide. Required reading for scholars interested in the history of early twentieth-century ballet, Early Memoirs is a source that must be used with care as a window into Nijinska's memories and sensibility.

\section{NOTES}

I am deeply grateful to Elizabeth Aldrich, Curator of Dance, Performing Arts Division, Library of Congress, for her unstinting support of this project and to Maria Cook for her assistance in summarising and translating most of the unpublished material in Russian.

1. Bronislava Nijinska, Early Memoirs, trans. and ed. Irina Nijinska and Jean Rawlinson, introd. Anna Kisselgoff (New York: Holt, Rinehart and Winston, 1981) (hereafter EM). For this volume only, page numbers will be embedded in the text.

2. Lynn Garafola, 'Book News: Nijinska's Story', The Dancing Times, Feb. 1982, p. 341.

3. See, for example, Richard Buckle, Nijinsky (New York: Simon and Schuster, 1971); V. Dandré, Anna Pavlova in Art and Life (London, 1932; rpt. New York: Arno Press, 1972, 1979); The Decorative Art of Léon Bakst (London, 1913; rpt. New York: Dover, 1972); Oleg Kerensky, Anna Pavlova (New York: Dutton, 1973); Charles Spencer, Léon Bakst (London: Academy Editions, 1973); V. Svetloff, Anna Pavlova, trans. A. Grey (Paris, 1922; rpt. 
New York: Dover, 1974); Cyril W. Beaumont, Bookseller at the Ballet: Memoirs 1891 to 1929 (London: C. W. Beaumont, 1975); Serge Lifar, Serge Diaghilev: His Life, His Work, His Legend: An Intimate Biography (New York, 1940; rpt. New York: Da Capo, 1976); Alexandre Benois, Reminiscences of the Russian Ballet, trans. Mary Britnieva (London, 1941; rpt. New York: Da Capo, 1977); Mathilde Kschessinska, Dancing in Petersburg: A Memoir of Imperial Russia Exile and the Ballet, trans. Arnold Haskell (Garden City, N.Y., 1961; rpt. New York: Da Capo, 1977); Arnold Haskell, Diaghileff: His Artistic and Private Life (London, 1935; New York: Da Capo, 1978).

4. The full typescript of the English translation is in Box 1, Folder 2, Bronislava Nijinska Collection, Music Division, Library of Congress (hereafter BNC). Incomplete and draft versions of the material in English and Russian are scattered throughout the collection.

5. Bronislava Nijinska (hereafter BN), draft letter to Andrei Anatolievich Shaikevich (André Schaikévitch), [1971]. In notebook titled 'Letters 1971', Box 65, Folder 2, BNC. Translation by Maria Cook. Schaikévitch (1903-72), who was married to the RussoFrench dancer Nina Tikanova who had worked with Nijinska in the late 1920s and 1930s, was a critic and the author of several books about ballet, including Mythologie du ballet: de Vigano à Lifar (Paris: Corrêa, 1939), Serge Lifar et le ballet contemporain (Paris: Corréa, 1950); Olga Spessivtzeva, magicienne envoutée (Paris: Librairie les Lettres, 1954), and Serge Lifar et le destin du Ballet de l'Opéra (Paris: Richard-Masse, 1971).

6. Multiple versions of 'Movement and the School of Movement' exist in the Nijinska papers. See, for example, Box 55, Folders 3, 7, and 8, BNC. There are also two quite different published versions: 'On Movement and the School of Movement', in Schrifttanz: A View of German Dance in the Weimar Republic, ed. Valerie Preston-Dunlop and Susanne Lahusen (London: Dance Books, 1990), pp. 55-60 (originally published in April 1930); 'On Movement and the School of Movement', trans. Thelwall Proctor), ed. and introd. Joan Ross Acocella and Lynn Garafola, in Nancy Van Norman Baer, Bronislava Nijinska: A Dancer's Legacy (San Francisco: The Fine Arts Museums of San Francisco, 1986), pp. 85-8. A draft of the considerably longer 1918 treatise, 'The School and Theater of Movement', is in Box 55, Folder 5, BNC.

7. James Kennedy, 'La Nijinska', The Guardian, 7 Nov. 1964, p. 7.

8. The author had numerous conversations with Irina Nijinska over the years, attended rehearsals for a number of her productions, and also interviewed her for Dance Magazine ('The Exemplary Daughterhood of Irina Nijinska', Dance Magazine, June 1989, pp. 43-4).

9. Daroff (Anatolii Andreevich Darov), who left the Soviet Union in 1944, was best known for his novel Blokada (Blockade), which was was published in French as Le Soleil luit quand-même (Paris: Gallimard, 1959). His letters to Nijinska are in Box 71, Folder 8; drafts of her letters to him in Box 65, Folders 1-2, BNC. Previously she had approached Tatiana Pavlovna Fesenko, a writer and editor who worked at the Library of Congress. Fesenko initially agreed to take on the job, but demurred when she realised that it demanded rewriting as well as copyediting. Like most of Nijinska's editorial and publishing contacts, Daroff and Fesenko were recommended to Nijinska by the composer Vladimir Dukelsy/Vernon Duke. Daroff's letters are in Box 71, Folder 8; Fesenko's in Box 72, Folder 40, BNC.

10. Drafts of Nijinska's letters to Wollard are in Box 65, Folder 2, BNC.

11. Mosty, a 'Literary-Artistic and Social-Political Almanach', was published in Munich, although in 1967 the editorial offices moved to New York. The annual ceased publication after 1970.

12. George Ivásk, letter to BN, 6 Oct. 1968, Box 73 Folder 24, BNC. In her letter of 16 Sept. 1968, Nijinska addresses him as Iurii Pavlovich.

13. In the draft of a letter to Natalie Wollard dated 6 May 1971, Nijinska writes referring to the Diaghilev chapter: 'The late Dukelsky [he had died in 1969] liked it so much that he wanted to publish it in the journal "Mosty," but I firmly refused-I don't want to participate in any émigré journals' (Box 65, Folder 2). Her initial letter to Ivásk (16 September 1968) certainly contradicts this: 'I am sending you chapters from my book so you can quickly familiarize yourself with them, and, also, as you have kindly agreed to edit them. Forgive the delay in sending you the copy of these chapters from my book to shape and edit, as Vladimir Aleksandrovich [Vernon Duke] proposed for the journal 
"Bridges"... I I would be very happy if after reading. . . the chapters. .., you would agree to edit the whole book' (Box 73, Folder 24).

14. BN, draft of a letter to Natalie Wollard, 1 Nov. 1971, Box 65, Folder 2, BNC. This and other letters in this file are the source of the account that follows.

15. The Soviet publications to which Nijinska refers are almost certainly the chapter on her brother in the first volume of Vera Krasovskaia's Russkii baletnyi teatr nachala XX veka (Russian Ballet Theater in the Early Twentieth Century) (Leningrad: Iskusstvo, 1971), and her biography of the dancer published three years later (Nizhinskii Leningrad: Iskusstvo, 1974)]. The 'London' book was Richard Buckle's Nijinsky (London: Weidenfeld and Nicolson, 1971).

16. BN, draft of a letter to Natalie Wollard, 1 Nov. 1971, Box 65, Folder 2, BNC. For Béjart's ballet, see Oleg Kerensky, 'Nijinsky: Clown of God,' The Guardian, 15 Oct. 1971, p. 10; Alan M. Kiriegsman, 'Camera Three: Focus on Béjart,' The Washington Post, 27 Nov. 1927, E1.

17. BN, draft of a letter to Nathalie Wollard, 6 May 1971, Box 65, Folder 2, BNG.

18. Bertha Klausner, letter to BN, 20 June 1968, Box 73, Folder 41, BNC.

19. BN, draft of a letter to Bertha Klausner, 6 Oct. 1968, Box 73, Folder 41, BNC. The letter, in English, is in Irina Nijinska's handwriting.

20. Jean M. Serafetinides (Rawlinson), draft of a letter to Paul McClusky, Harcourt Brace Jovanovich, New York, [1973?], Box 19, Folder 26, BNC.

21. Jean M. Serafetinides (Rawlinson), draft of a letter to Bertha Klausner, [1974], Box 19, Folder 26, BNC.

22. Bertha Klausner, photocopy of a letter to Jean M. Serafetinides (Rawlinson), 16 Mar. 1974, Box 19, Folder 26, BNC.

23. 'Creation of "Les Noces": Bronislava Nijinska', trans. and introd. Jean M. Serafetinides (Rawlinson) and Irina Nijinska, Dance Magazine, Dec. 1974, p. 58. A copy of Rawlinson's 'Final Draft' is in Box 19, Folder 15, BNC.

24. BN, draft of letters to Natalie Wollard, of 25 Apr. 1971, 2 Aug. 1971, 1 Nov. 1971; and Nathalie Wollard to BN, 6 Nov. 1971, Box 65, Folder 2, BNC.

25. 'The Dancing Family of Nijinsky's - 1856-1914', typescript, Box 40, Folder 1, BNC. The credit line on the title page reads: 'by Bronislava Nijinska. Presented in English and edited by Irina Nijinska and Jean M. Serafetinides' (Rawlinson's maiden name). A second title page following page 123 identifies the manuscript as being 'from the Memoirs of Bronislava Nijinska'.

26. 'My Brother Vaslav Nijinsky', typescript of the first 130 pages of the English translation with additional writings, p. 107. Box 47, Folder 2, BNC.

27. Ibid., p. 106.

28. Ibid., p. 56.

29. Ibid. This comes from the second page of Chapter 6. Slight changes have been made in punctuation.

30. Bronislava Nijinska, 'Draft-Early Memoirs', Russian typescript with Nijinska's handwritten corrections, pp. 30-1. Box 32, Folder 1, BNC. Translation by the author.

31. Bronislava Nijinska, 'School and Theatre of Movement 1918', p. 59. Box 55, Folder 5, BNC.

32. 'Do you remember how Pavlova approached an arabesque? This is how one should learn movement. Or Nijinsky? Do you remember how many transitions, how many nuances there were in the course of his leap? These transitions and nuances created the illusion that he never touched the ground. Do you remember how Pavlova approached her pas? Well, this approach is movement. All Pavlova's enchantment lay in how she moved into an attitude, arabesque, or other position. Geniuses of the dance like Vaslav Nijinsky and Anna Pavlova thrilled us because in their dancing was the true nature of movement, born unconsciously of their genius and not of a school. It is strange that these two artists, creators of a whole epoch in dance and of unprecedented enthusiasm for dance throughout the world, never found their true successors' ('On Movement and the School if Movement', in Baer, p. 86). 
33. See, for instance, 'Pavlova and Nijinsky, 1907, "Chopiniana", in 'My Brother Vaslav Nijinska', n.p., Box 47, Folder 2, BNC; and "'Giselle," Anna Pavlova and Nijinsky,' typescript in Russian of Bronislava Nijinska's 'Iz dnevnika molodoi tantsovshchitsy, 1910-1912' (From the Diary of a Young Dancer, 1910-1912), unpublished manuscript dated New York, 1942, Chapter 2 in the St. Petersburg section. There are multiple versions of this manuscript. See, for example, Box 32, Folders 4, 6; also Box 2, Folder 8 for an English translation, BNC. Most of this material was incorporated into Early Memoirs, pp. 282-3.

34. This is indicated on page 22 in the Russian typescript in Box 32, Folder 1, BNC. (A typescript of the English translation reads: 'From the book of Vera Krassovska [sic] "History of the Russian Ballet" it is known that Nijinsky danced the "Blue Bird" for the first time in the Maryinsky Theatre with Lydia Kiaksht, November 27, 1907'), n.p. Box 47, Folder 2, BNC. The Nijinsky chapter is in Vera Krasovskaia, Russkii baletnyi teatr nachala $X X$ veka (Russian Ballet of the Early Twentieth Century), vol. 1 (Leningrad: Iskusstva, 1971), pp. 385-448. In an undated note Irina Nijinska writes that in December 1967 Krasovskaia sent Nijinska her chapter on Nijinsky and asked her 'to read her manuscript and to send her corrections or additions'. Undated note, 'Drafts/Notes - Creative Years', Box 40, Folder 3, BNC.

35. Buckle's misquote of Debussy's letter to Robert Godet is in Nijinsky, p. 290; the correct version in Edward Lockspeiser, Debussy: His Life and Mind, vol. 2 (New York: Macmillan, 1965), p. 172; and the detailed - and erroneous - explanation in EM, p. 469.

36. Tamara Karsavina, Theatre Street: The Reminiscences of Tamara Karsavina (London: Heinemann, 1930), pp. 190-5, 201-2; Buckle, Nijinsky, p. 36.

37. V[ladimir] A[rkad'evich]Teliakovskii, Imperatorskie teatry i 1905 god (The Imperial Theaters and 1905), ed. E. M. Kuznetsov, pref. A. A. Gvozdev (Leningrad: Academia, 1926).

38. Irina Nijinska's rough translations, typed and with handwritten edits, are in Box 40, Folder 2, BNG.

39. M[ikhail] Borisoglebskii, Proshloe baletnogo otdelenniia Peterburskogo teatralnogo uchilischa, nyne Leningradskogo gosudarstvennogo khoregraficheskogo uchilishcha; materialy po istorii russkogo baleta (The Past of the Ballet Department of the Petersburg Theatrical School, Today the Leningrad State Choreographic School: Materials for the History of Russian Ballet), 2 vols. (Leningrad: Leningrad State Choreographic School, 1938-9).

40. Irina's notes are in Box 40, Folder 2, BNC.

41. A clean Russian typescript of 'Prince Lvov: Friend of Our Family' is in Box 32, Folder 1, BNC. The chapter runs from pages 23-35 of Nijinska's typescript.

42. There are multiple versions of this chapter. The one I quote is a typescript of the English translation by Nathalie Wollard in Box 35, Folder 4, BNC. A clean Russian typescript, with the notation 'Copy for Ivaska (?)', is in Box 34, Folder 3, BNC.

43. BN, draft of letter to André Schaikévitch, [1971], Box 65, Folder 2, BNC.

44. See, for example, Waldemar George, 'Propos de Danse: Les Idées de Mademoiselle Nijinska', Le Crapouillot, 1 September 1922, p. 9; Marc Semenoff, 'La Danse', Le Courrier Musical, 1 Nov. 1930, p. 641; 'Un entretien avec Mme Nijinska', Le Courier Musical, 1 Apr. 1931, pp. 216-17; and 'Un entretien avec Bronislawa Nijinska', Le Journal des Débats, 6 June 1932, Box 116, BNC.

45. Romola Nijinsky, Nijinska, foreword by Paul Claudel (London: Gollancz, 1933).

46. 'Nijinski's Sister Here', New York Times, 15 Nov. 1934, p. 24.

47. Anatole Bourman, with Dorothy Lyman, The Tragedy of Nijinsky (NewYork: McGraw-Hill, 1936).

48. Irina Nijinska, unidentified notes, Box 40, Folder 3, BNC.

49. Undated typescript in Russian outlining a volume of memoirs beginning with Nijinsky's 1914 company and ending roughly in 1936, Box 34, Folder 15, BNC.

50. There are numerous versions of this manuscript, including an uncredited English translation, in Box 1, Folder 8; Box 32, Folders 4, 6, 7; and Box 48, Folder 4.

51. She used the phrase in 1935 when she visited the Hollywood Bowl and told a reporter from the Los Angeles Times, 'This makes me think of my home city, Kiev, where they have music outdoors in the summer, too. In Russia and California they have vast spaces. 
I love it! France is small, compressed, of necessity. Here, in the Hollywood Bowl, we could do things on a grand scale!' Isabel Morse Jones, 'Camera Angles Supersede Music, Art, Nijinska Finds', Los Angeles Times, 20 Jan. 1935, p. A6.

52. This meeting took place in the winter of 1992 when I was a scholar in residence at the Getty Center for the History of Art and the Humanities.

53. Isadora Duncan, My Life (New York: Boni and Liveright, 1927); Michel Fokine, Memoirs of a Ballet Master, trans. Vitale Fokine, ed. Anatole Chujoy (Boston: Little, Brown, 1961); Martha Graham, Blood Memory (New York: Doubleday, 1991). For authorship of Duncan's memoirs, see Peter Kurth, Isadora: A Sensational Life (Boston: Little, Brown, 2001), chaps. 29-30; for the preparation of Fokine's memoirs, Chujoy's 'Editor's Note', Memoirs of a Ballet Master, vii. According to Elizabeth Aldrich, who processed the Martha Graham materials at the Library of Congress, the drafts of Blood Memory were edited by Ron Protas. 